\title{
Carga inmediata en implantes dentales
}

\author{
Immediate loading of dental implants
}

\author{
C. Concejo Cútoli, N. Montesdeoca García
}

Resumen: El protocolo de carga convencional en una o dos fases quirúrgicas ha sido evaluado durante los últimos 30 años bajo todas las condiciones clínicas posibles. En comparación, la carga inmediata es un protocolo relativamente nuevo que necesita de una estricta evaluación clínica. Realizamos una búsqueda bibliográfica sobre los ensayos clínicos publicados de carga inmediata en función de las diferentes opciones terapéuticas que se pueden plantear. Se hallaron resultados comparables para las dos estrategias de carga en mandíbulas edéntulas. Para el tratamiento con prótesis inmediata de maxilares totalmente edéntulos, restauraciones parciales e unitarias es todavía necesaria una selección adecuada de pacientes y un diseño conservador de la prótesis provisional. La necesidad de ensayos clínicos sencillos aleatorizados de doble ciego, con suficiente número de pacientes y adecuado seguimiento, que comparen una determinada situación clínica con un patrón oclusal de la prótesis provisional bien definido, son imprescindibles para acabar de confirmar la seguridad de la técnica.

Palabras clave: Carga inmediata; Implantes dentales.

Recibido: 03.10.2005

Aceptado: 17.10.2005

\begin{abstract}
The protocol for conventional loading in one or two surgical stages has been evaluated over the last 30 years under all the possible clinical conditions. By comparison, immediate loading is a relatively new protocol that requires strict clinical evaluation. We conducted a search of the literature published concerning clinical trials on immediate loading according to the different therapeutic options that could be considered. Comparable results were found for both loading strategies in edentulous mandibles. For treatment involving an immediate prosthesis for totally edentulous mandibles, partial and single tooth restorations, patients have to be selected adequately and provisional prostheses have to be designed conservatively. In order to completely confirm the safety of the technique, double-blind, simple, randomized clinical trials have to be carried out with a sufficient number of patients and proper followups that compare precise clinical situations with a provisional prosthesis that has a specific occlusion pattern.
\end{abstract}

Key words: Immediate loading; Dental implants.

\footnotetext{
1 Cirujano Oral y Maxilofacial, Jefe de Servicio.

2 Médico Adjunto.

Servicio de Cirugía Oral y Maxilofacial. Clínica Universitaria.

Universidad de Navarra. Pamplona. España

Correspondencia:

Dr. Carlos Concejo Cútoli.

Departamento de Cirugía Oral y Maxilofacial.

Clínica Universitaria. Universidad de Navarra

Avda. Pío XII, 36, 31008 Pamplona, España

Email: cconcejo@unav.es
} 


\section{Introducción}

Los implantes dentales se han convertido en una técnica rutinaria y predecible, siendo a día de hoy el estándar terapéutico para la reposición de piezas dentales en adultos. Un implante oral osteointegrado se ancla directamente al hueso, sin embargo, en presencia de movimiento, una interfase de tejido blando puede encapsular el implante, provocando su fracaso. ${ }^{1}$

El protocolo clásico establecido por Brånemark se encuentra actualmente en discusión. Durante los últimos 15 años varios autores han confirmado el éxito de la integración de los implantes dentales en una sola fase quirúrgica, ${ }^{2}$ eliminando la necesidad de descubrir el implante en un segundo procedimiento. Como resultado aumentó la comodidad del paciente y se obtenían tejidos blandos maduros previos a la fabricación de prótesis.

La mejora en la superficie de los implantes produjo una disminución en los tiempos de carga convencional con un éxito comparable al protocolo estándar. Implantes con superficie SLA (ITI Dental Implant System, Institut Straumann, Waldenburg, Suiza) han sido cargados con éxito a las seis semanas. ${ }^{3}$

Aunque Lederman en 19794 fue el primero en introducir el concepto de carga inmediata mediante la utilización de implantes con superficie chorreada con plasma de titanio, obteniendo una supervivencia global del $91,2 \%$ con un seguimiento a 81 meses. No fue hasta 1990 cuando Schnitman, ${ }^{5}$ público la primera serie de pacientes en la cual se sugirió que los implantes podrían cargarse de inmediato en las mandíbulas de pacientes seleccionados con una supervivencia comparable al protocolo estándar.

\section{Histología de la carga inmediata}

El periodo de mayor riesgo para los implantes es el comprendido entre la segunda y la cuarta semana después de su colocación. En este periodo decrece temporalmente la estabilidad primaria. La estabilidad mecánica del implante lograda mediante el atornillado al hueso empieza a disminuir porque los osteoclastos comienzan el proceso de reabsorción ósea. La de formación de nuevo hueso, en el que los osteoblastos aportan nuevos contactos óseos, no está lo suficientemente avanzada para proveer al implante de gran estabilidad secundaria. Estudios de análisis de la frecuencia de resonancia demuestran que los implantes con buena estabilidad inicial la mantienen de tres a cuatro meses tras su puesta en función. ${ }^{6}$ Implantes con bajos valores de estabilidad después del primer o segundo mes de carga inmediata tienen un alto riesgo de fracaso. ${ }^{7}$

Cierto grado de micromovimiento es beneficioso para la estimulación de los osteoblastos, el hueso responde favorablemente a las cargas compresivas y estudios experimentales encontraron entre un 60 y $80 \%$ de contacto hueso-titanio en la superficie de los implantes cargados de forma inmediata. ${ }^{8}$ Sin embargo, la prevención del micromovimiento es crítica para evitar la formación de tejido fibroso alrededor del implante, no debiendo ser mayor de 50 o $100 \mu \mathrm{m}$, rangos de movimiento superiores a $150 \mu \mathrm{m}$ pueden comprometer la osteointegración. ${ }^{9}$

\section{Introduction}

Dental implants are now part of a routine and predictable technique, and they are today the therapeutic standard according to which teeth are replaced in adults. An osseointegrated oral implant is anchored directly into bone, however, if there is movement, a soft-tissue interface can encapsulate the implant leading to failure. ${ }^{1}$

The classical protocol established by Branemark is currently under debate. During the last 15 years various authors have confirmed the successful2 integration of dental implants in a single surgical stage, thus eliminating the need for exposing the implant in a second surgical stage. This resulted in improved patient comfort, and mature soft tissue was obtained before making the prosthesis.

The improvement in implant surfaces led to conventional loading times being reduced and the success rate was comparable to that of the standard protocol. Implants with SLA surfaces (ITI Dental Implant System, Institut Straumann, Waldenburg, Switzerland) have been successfully loaded at six weeks. ${ }^{3}$

In 1979 Lederman, ${ }^{4}$ was the first to introduce the concept of immediate loading with titanium plasma-sprayed coatings, and he obtained a global survival rate of $91.2 \%$ after a follow-up of 81 months. But it was not until 1990 when Schnitman, ${ }^{5}$ published the first series of patients that it was suggested that implants could be loaded immediately in the mandibles of selected patients, and that the survival rate was comparable with that of the standard protocol.

\section{Histology behind immediate loading}

The period with the greatest risk for implants is between the second and fourth week after placement. During this period primary stability decreases temporarily. The mechanical stability of the implant achieved by means of screwing it to the bone begins to diminish because the osteoclasts begin the process of bone resorption. The formation of new bone, during which the osteoblasts make new bone contact, is not sufficiently advanced to provide the implant with strong secondary stability. Resonance frequency analysis studies have shown that implants with good initial stability maintained this three to four months after attachment. ${ }^{6}$ Implants with low stability values after the first or second month of immediate loading have a high risk of failing. ${ }^{7}$

A certain degree of micromovement is beneficial for stimulating the osteoblasts. Bone responds favorably to compressive loads and experimental studies found bone-titanium contact of 60 to $80 \%$ on implant surfaces that had been loaded immediately. ${ }^{8}$ However, preventing micromovement is critical for avoiding the formation of fibrous tissue around the implant, and this should not be above 50 to $100 \mu \mathrm{m}$. Movement ranges above $150 \mu \mathrm{m}$ can jeopardize osseointegration. $^{9}$ 


\section{Estabilidad primaria}

La estabilidad del implante tras su inserción es el factor de éxito más importante para la osteointegración. ${ }^{10}$ La estabilidad primaria de los implantes viene determinada inicialmente por la densidad ósea, estructura trabecular del hueso, la técnica quirúrgica, el número y diseño de los implantes utilizados y su distribución en la arcada dentaria. Posteriormente es favorecida por un correcto diseño oclusal que controle las cargas masticatorias, la ausencia de extensiones y la unión rígida de todos los implantes por la prótesis provisional.

Tan importante es la densidad y la estructura trabecular como la celularidad del hueso que va a albergar los implantes.

\section{Cuantificación de la estabilidad primaria}

La evaluación de la carga inmediata requiere de un método cuantitativo para la medición de la estabilidad del implante. La objetivación intraoperatoria de la estabilidad del implante es crucial para la toma de decisiones respecto a la carga inmediata. Desde un punto de vista práctico hay varias técnicas que permiten aproximarnos a la estabilidad clínica del implante previa a su carga, aunque ninguna de ellas ha sido todavía formalmente aceptada como referencia a día de hoy.

Johansson y Strid, ${ }^{11}$ desarrollaron la medición del torque de corte durante la preparación de la osteotomía a bajas revoluciones (OsseoCare; Nobel Biocare, Göteborg, Suecia), permitiendo medir la resistencia que ofrece el hueso al trabajó de la pieza de mano. Expresa la densidad ósea en función de la energía requerida para cortar por unidad del volumen óseo. Así, una densidad ósea baja necesitaría menos de $30 \mathrm{Ncm}$ para la colocación del implante, la densidad ósea media oscila entre 30 y $40 \mathrm{Ncm}$ y la densidad alta supera los 40 $\mathrm{Ncm}$. Para cargar implantes de forma inmediata se recomienda un torque de inserción comprendido entre 35 y $45 \mathrm{Ncm}$.

El análisis de la frecuencia de resonancia (Osstell; Integration Diagnostics, Götegorg, Suecia) es un método no invasivo desarrollado por el Dr. Neal Meredith, ${ }^{12}$ para cuantificar la estabilidad del implante analizando la interfase hueso-titanio. En este caso, un transductor eléctrico emite un pequeña onda de vibración sobre un material piezo-cerámico atornillado al implante y un receptor recoge las variaciones en la frecuencia que sufre esa onda. Mide la frecuencia de resonancia en un rango de 3.500 a $8.500 \mathrm{~Hz}$, estos valores han sido trasladados a un índice más manejable que varía entre 0 y 100, el ISQ (Implant Stability Quotient). En la experiencia de los autores, ${ }^{13}$ valores inferiores a 40 implican situaciones de alto riesgo para el implante mientras que valores superiores a 55 son considerados favorables. Queda por establecer qué valores serían recomendables para la carga inmediata, se postula que valores comprendidos entre 60 y 80 con estabilidad antirrotacional serían adecuados para esta técnica. Caso 1 (Figs. 1-4).

\section{Selección del implante}

El tipo de implante idóneo para la carga inmediata está todavía por desarrollarse, en este sentido, innovaciones en su macroestructura (diseño) y microestructura (superficie) han contribuido a
Primary stability

The stability of the implant after insertion is the most important factor influencing successful osseointegration. Primary stability of the implants is initially determined by bone density, trabecular bone structure, surgical technique, by the number and design of the implants used, and their distribution in the dental arch. Later this is helped by a correct occlusal design to control the masticatory forces, an absence of extensions, and the firm union of all implants by the provisional prosthesis.

The density and trabecular structure is as important as the bone marrow cellularity that will house the implants.

\section{Primary stability quantification}

In order to evaluate immediate loading, a quantitative method is needed for measuring implant stability. An objective intraoperative assessment of implant stability is crucial for making decisions with regard to immediate loading. From a practical point of view there are various techniques that will give an idea of the clinical stability of the implant before loading, although to date none of these have been formally accepted as a reference.

Johansson y Strid, ${ }^{11}$ developed the cutting torque measurements during the preparation of the low-power osteotomy (OsseoCar; Nobel Biocare, Göteborg, Sweden), which allowed measuring bone resistance on drilling. Bone density was expressed according to the energy required to cut each unit of bone volume. Thus, low-density bone would need at least $30 \mathrm{Ncm}$ for placing an implant, medium density bone varies between 30 and $40 \mathrm{Ncm}$ and high density is over $40 \mathrm{Ncm}$. For immediate loading implants, an insertion torque is recommended between 35 and $45 \mathrm{Ncm}$.

Resonance frequency analysis (Osstell; Integration Diagnostics, Götegorg, Sweden) is a non-invasive method developed by Dr. Neal Meredith 12 for making quantitative measurements of the stability of the implant by analyzing the bonetitanium interface. In this case an electric transducer sends a vibration wavelet over piezo-ceramic material screwed to the implant and a receptor picks up the frequency variations of the wave. It measures the resonance between 3.500 and $8.500 \mathrm{~Hz}$. These values have been transferred to a more manageable index that varies between 0 and 100, the ISQ (Implant Stability Quotient). The experience of many authors 13 shows that values under 40 imply a high-risk situation for the implant, whereas values over 55 are considered favorable. The values that should be recommended for immediate loading have yet to be established. It has been postulated that values between 60 and 80 with antirotational stability could be adequate for this technique. Case 1 (Figs. 1-4).

\section{Implant choice}

The type of implant most suited for immediate loading has still to be developed, but in this sense, innovations in 
mejorar su estabilidad y pronóstico ante una situación tan estresante.

No hay publicados Ensayos Clínicos Aleatorizados (ECA) que comparen dos tipos diferentes de superficies rugosas bajo carga inmediata. De hecho, la mayoría de superficies patentadas por las diferentes casas comerciales han sido autorizadas por la FDA para carga inmediata en pacientes con mandíbulas edéntulas. En un reciente meta-análisis de Espósito, ${ }^{14}$ no encuentra diferencia entre los implantes con diferentes preparaciones de la superficie. No hay evidencia sólida para demostrar que algún tipo particular de implante dental tiene tasas superiores de éxito a largo plazo.

La macroestructura del implante es capaz de mejorar por sí sola la estabilidad primaria tras la cirugía. En el hueso D1 y D2 la transmisión de fuerzas a lo largo del eje del implante se produce sobre hueso cortical. Este hueso es 10 veces más rígido que el hueso esponjoso, esto explicaría el porqué la longitud del implante y su forma no juegan un papel crítico en estas densidades. ${ }^{15}$

En el hueso D4 la cortical es muy fina o inexistente, el implante está rodeado de hueso esponjoso muy elástico y las fuerzas son transmitidas hacia la porción apical del implante, que no tiene resistencia suficiente para soportar la carga inmediata. Estudios de análisis de elementos finitos demostraron que en huesos de baja densidad era más relevante la distribución de las fuerzas que el volumen óseo existente. ${ }^{16}$ La utilización de implantes de diseño anatómico, con disminución del diámetro en sentido cérvico-apical y plataforma más ancha, permite un fuerte asentamiento sobre la cortical. El paso de rosca decreciente, no cortante en la porción apical, ayuda a compactar el hueso más esponjoso.

En hueso poco denso los implantes roscados presentan mayor cantidad de contacto hueso-implante que los cilíndricos. Pero tienen el problema de que si son asentados con excesivo torque pueden romper la rosca que crean en el lecho perdiendo su estabilidad inicial. Por eso los implantes con doble sistema de rosca o muescas en la misma proporcionan mayor estabilidad. ${ }^{17}$

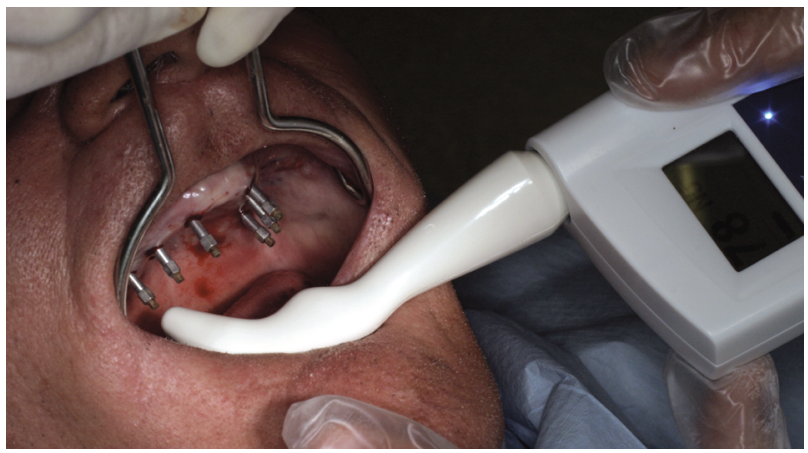

Figura 1. Aparato Ostell para medir la frecuencia de resonancia de los implantes. Valores entre 60 y 80 Unidades se consideran aptos para la caraga inmediata.

Figure 1. Ostell device for measuring the resonance frequency of implants. Values between 60 and 80 units are considered suitable for immediate loading.

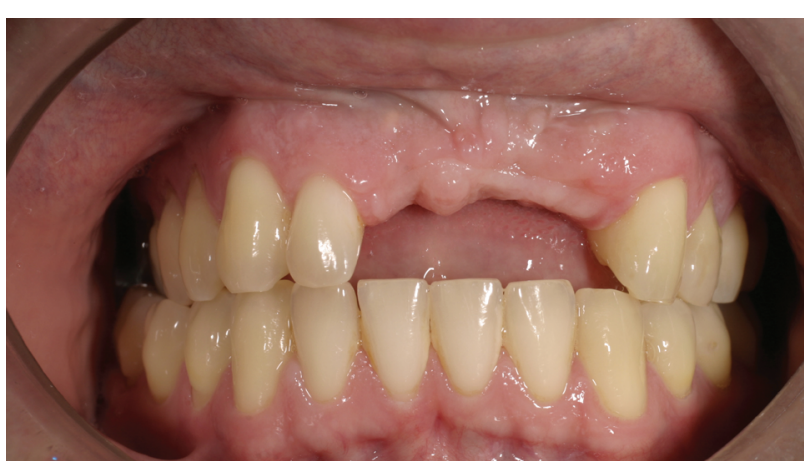

Figura 2. Las brechas anteriores en pacientes con adecuado volumen óseo son una de las indicaciones establecidas para realizar carga inmediata.

Figure 2. The anterior gaps in patients with adequate bone volume are one of the indications established for carrying out immediate loading.

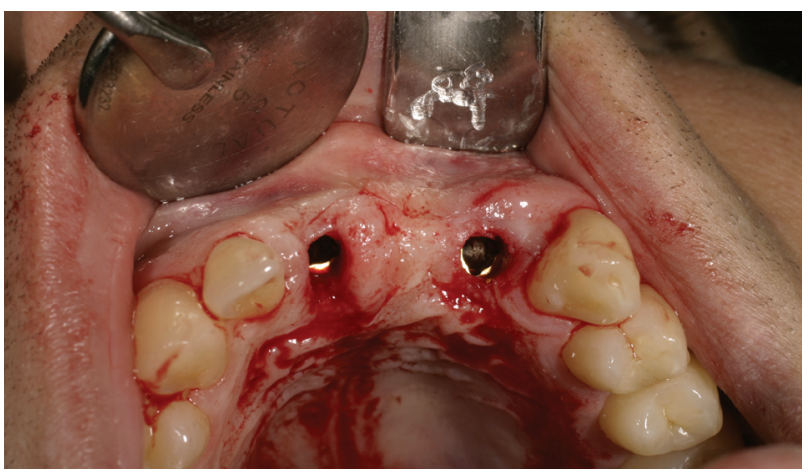

Figura 3. La cirugía minimamente invasiva cuando se asocia a una carga inmediata de los implantes favorece la preservación de los tejidos blandos en zonas de especiales requerimientos estéticos. Figure 3. Minimally invasive surgery when associated with immediate loading of implants favors the preservation of soft tissue in areas with special aesthetic requirements. macrostructure (design) and microstructure (surface) have contributed to improving stability and prognosis under such stressful situations.

Randomized clinical trials (RCT) that compare two different types of rough surfaces under immediate loading have not been published. In fact, most surfaces that have been patented by different manufacturers have been authorized by the FDA for immediate loading in patients with edentulous lower jaws. In a recent meta-analysis by Esposito ${ }^{14}$ no difference was found between various types of implant surfaces. There is no solid evidence that demonstrates that a certain type of dental implant has a higher success rate in the long term. The macrostructure of the implant itself is capable of improving primary stability following surgery. In D1 and D2 bone, force transmission along the implant axis is produced on the cortical bone. This bone is ten times more rigid than spongy bone, which explains why implant length and shape do not play a critical role in these densities. ${ }^{15}$

In D4 bone the cortex is very thin or inexistent, the implant is surrounded by spongy bone that is very elastic and the forces are transmitted towards the apical portion of the implant that does not have sufficient resistance for supporting immediately loading implants. Finite-element analyses showed that in lowdensity bone, the distribution of forces was more relevant than existing bone volume. ${ }^{16}$ The use of anatomically designed implants, with a reduction of the cervico-apical diameter and with a wider platform, allows a strong consolidation on the cortical bone. 
En este tipo de densidad debemos conseguir la mayor superficie de contacto, recomendándose colocar el mayor numero de implantes posibles con la máxima longitud que se pueda. La estabilidad primaria puede ser mejorada incrementando el diámetro del implante. ${ }^{18}$

\section{Técnica quirúrgica}

Varios estudios señalan que la supervivencia de los implantes está directamente relacionada con la experiencia del cirujano. ${ }^{19}$ La mayoría de los magníficos resultados publicados son logra-

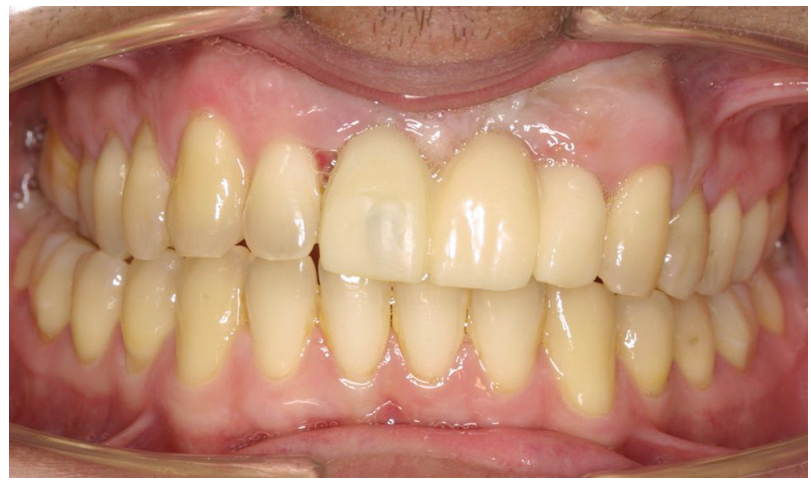

Figura 4. Prótesis provisional de acrílico implantosoportada colocada a las pocas horas de realizar la colocación de los implantes. Figure 4. Provisional implant-supported acrylic prosthesis placed a few hours after implant placement. dos por equipos con gran experiencia.

La técnica quirúrgica que garantice una estabilidad primaria del implante está estrechamente relacionada con la calidad ósea. En el hueso D1 los mayores problemas pueden venir determinados por necrosis térmica del hueso periimplantario. El hueso cortical disipa peor el calor que el hueso esponjoso y tiene más riesgo de sobrecalentamiento. ${ }^{20}$ Se necesitan sistemas de corte altamente efectivo y poco traumático. Los implantes no deben ser colocados a la máxima presión, pero si a un torque suficiente para garantizar la estabilidad antirrotacional del implante. Los implantes con poca estabilidad primaria en este tipo de hueso tienen especialmente un mal pronóstico.

En los tipos D2 y D3 se recogen los mejores resultados, el aterrajado del lecho no es necesario en los implantes roscados. Se prefiere el uso de anclaje bicortical para mejorar la estabilidad primaria en el suelo de la fosa nasal y en el seno maxilar.

En hueso D4 la gran mayoría de fallos están relacionados con la falta de estabilidad. La respuesta del hueso trabecular al estrés mecánico es especialmente crítica.

\section{Selección de pacientes}

La mayoría de los artículos publicados sobre carga inmediata han sido realizados sobre pacientes seleccionados. Sin embargo, otros autores sugieren que los grupos de pacientes de carga inmediata no difieren de aquellos en los que se ha realizado carga convencional. ${ }^{21}$

De forma genérica se evita realizar en pacientes cuya condición médica implique una disminución de la calidad ósea suficiente para comprometer la estabilidad primaria o que presumiblemente tengan problemas de microperfusión en el hueso.

La osteoporosis primaria o secundaria no supone una contraindicación absoluta para la carga inmediata.

Se necesita un volumen óseo suficiente para colocar un implante de mínimo $10 \mathrm{~mm}$ de longitud y 3,75 mm de diámetro, debiendo estar rodeado por al menos $1 \mathrm{~mm}$ de hueso en sentido bucolingual. Las estructuras anatómicas pueden limitar la longitud de la fijación, recomendándose colocar más implantes para aumentar la superficie de osteointegración. Sin embargo, implantes de menos
A decreasing, non-cutting thread in the apical part, helps to compact spongier bone.

With regard to bone that is less dense, threaded implants have more bone-implant contact than cylinder implants. But if they are over screwed on placement there can be a problem with breaking the thread in the bed and initial stability is lost. But implants that have a double thread or notches provide greater stability. ${ }^{17}$

In this type of density we should aim to obtain the greatest surface contact. Placing the largest number of implants possible is recommended with the maximum length possible. Primary stability can be improved by increasing the diameter of the implant. ${ }^{18}$

\section{Surgical technique}

Various studies indicate that the survival of the implants is directly related with the experience of the surgeon..$^{19}$ Of the best results published, the majority are achieved by teams with great experience.

The surgical technique that guarantees the primary stability of the implant is closely related with bone quality. In D1 bone, most problems are determined by thermal necrosis of the peri-implant bone. Cortical bone dissipates heat worse than spongy bone, and there is a greater risk of it overheating. ${ }^{20}$ Cutting systems are needed that are highly effective and that cause little trauma. The implants should not be placed with maximum pressure, but they should be placed in a torque that is sufficient to guarantee the anti-rotational stability of the implant. Implants with little primary stability in this type of bone have a particularly bad prognosis.

The best results are to be found in D2 and D3 bone. Pretapping the site is not necessary for threaded implants. The use of bicortical anchorage for improving primary stability in the nasal fossa floor and in the maxillary sinus is preferred.

Most failures in D4 bone are related to lack of stability. The response of trabecular bone to mechanical stress is particularly critical.

\section{Patient selection}

Most of the articles published on immediate loading have been carried out on selected patients. However, other authors suggest that the immediate loading patients are no different from those that have undergone conventional loading. ${ }^{21}$

There is a generic tendency to avoid these placements in patient groups with medical conditions that imply reduced 
diámetro han sido cargados con éxito en hueso de buena calidad. Usar los implantes más largos posibles sobre hueso de mayor calidad justificaría la utilización de implantes angulados en la carga inmediata. El uso de injertos para aumentar el volumen óseo debe ser considerado previamente a la colocación de implantes para carga inmediata.

Clásicamente también se han excluido de estos estudios pacientes con alto grado de parafunción masticatoria. Hábitos como la presión lingual, el apretamiento dentario y el bruxismo pueden contraindicar la carga inmediata, no así la prótesis inmediata. Con un diseño oclusal en céntrica, la magnitud de la fuerza oclusal y la presencia de parafunción parece no ser un factor decisivo en la supervivencia de los implantes. ${ }^{22}$

La presencia de infección aguda no tratada en el lecho óseo contraindica la colocación del implante, no así en la proximidad si se realiza un buen legrado quirúrgico y tratamiento antibiótico.

Respecto a la radioterapia, no hay estudios publicados sobre carga inmediata.

\section{Diseño de prótesis en carga inmediata}

Desde el punto de vista organizativo no es desdeñable el esfuerzo de coordinación entre cirujano, prostodoncista y laboratorio a la hora de preparar la prótesis provisional dentro de las primeras 48 h. Para la resolución exitosa de los casos es necesario el planteamiento en equipo de trabajo para que la selección de los implantes, su distribución, y posición estén guiados por el plan de restauración.

Especial interés hay que mostrar en la distribución de los implantes en la arcada de pacientes edéntulos, optimizando el reparto de fuerzas y reduciendo la influencia de las extensiones y los contactos alejados del eje axial del implante. La restauración provisional es fabricada en material acrílico debiendo ferulizar a todos los implantes, cuando sea posible, mejorando la estabilidad biomecánica de los mismos. Es importante que dicha prótesis no sea retirada durante el proceso de osteointegración, antes de 3 meses. Si algún implante presentara signos de infección, éste debería ser tratado de forma conservadora si fuera posible. Desmontar la prótesis provisional antes de tiempo puede interferir en la osteointegración del resto de los implantes.

Distinguimos dos entornos oclusales de forma genérica, las arcadas totalmente edéntulas y las ausencias parciales o unitarias. La prótesis fija provisional en arcadas totalmente edéntulas deben tener una distribución adecuada pero limitada de contactos en relación céntrica o máxima intercuspidación, eliminando los contactos excursivos de la restauración y los contactos en la región molar cuando sea posible. ${ }^{23}$ Queda todavía por definir el papel que juegan las recomendaciones dietéticas postoperatorias y el tipo de dentición oponente.

En las restauraciones provisionales parciales o unitarias se deben evitar los contactos protusivos, laterales excursivos y las prematuridades. Pero ciertas situaciones clínicas hacen que las prótesis provisionales estén sujetas a contactos excursivos cuando la oclusión céntrica está ausente. Los implantes unitarios aún sin carga oclusal pueden estar sujetos a cargas laterales secundarias a la proximidad bone quality, as primary stability may be jeopardized and presumably there could be problems with bone microperfusion.

Primary or secondary osteoporosis does not imply that immediate loading is totally contraindicated.

A sufficient amount of bone volume is needed to place an implant with a minimum length of $10 \mathrm{~mm}$ and a diameter of $3.75 \mathrm{~mm}$, and it should be surrounded by at least 1 $\mathrm{mm}$ of bone in a bucco-lingual direction. Anatomical structures may limit the length of the device, and placing more implants is recommended in order to increase the osseointegration surface. However, implants with a shorter diameter have been loaded successfully in good quality bone. Using the longest possible implants on the best quality bone would justify the use of angulated implants for immediate loading. The use of grafts for increasing bone volume should be considered before placing immediately loading implants.

Traditionally patients with a high degree of masticatory parafunctions have also been excluded from these trials. Habits such as lingual pressure, clenching and bruxism can be adverse factors in immediate loading, but not for the immediate prosthesis. With a centric occlusal design, the strength of occlusal forces and the presence of parafunction does not appear to be a decisive factor in implant survival. ${ }^{22}$

The presence of acute untreated infection of the bony bed is contraindicative for placing an implant, but not if this is limited to an adjacent area providing proper surgical curettage and antibiotic treatment is carried out.

With regard to radiotherapy, there are no studies published covering immediate loading.

\section{Prosthesis design in immediate loading}

From the point of view of organization, the co-ordination effort between the surgeon, prosthodontist and laboratory should not be underestimated when preparing a provisional prosthesis within the first 48 hours. For successful case resolution, teamwork has to be considered, and the choice of implants, their distribution, and position should be guided by a restoration plan.

Special interest should be given to the distribution of implants in the arches of edentulous patients, with an optimum distribution of forces and a reduction of the effects of the extensions and all contacts should be away from the axial axis of the implant. The provisional restoration is made in acrylic material and all implants have to be splinted whenever possible, and biomechanical stability improved. It is important for the prosthesis not to be removed for 3 months during the osseointegration process. If any implant shows signs of infection, this should be treated as conservatively as possible. Dismounting a provisional prosthesis before time could interfere with the osseointegration of the remaining implants.

We should distinguish generally between two occlusal situations, totally edentulous arches and partial or single 
del bolo alimenticio. La habilidad del prostodoncista para distribuir la carga entre dientes naturales y prótesis sobre implantes es fundamental. Existe controversia sobre si deben quedar totalmente fuera de oclusión durante 2 ó 3 meses, 24,25 o pueden ser rehabilitadas en céntrica. Calandriello, rehabilitaba con éxito 50 molares con implantes anchos en oclusión céntrica, sin restricciones en la dieta de los pacientes. ${ }^{26}$

A nuestro parecer, preferimos dejar las restauraciones unitarias del sector anterior libres de carga cuando sea posible. Los premolares pueden ser ajustados en oclusión sin contactos en los movimientos protusivos y en laterales excursivos. Las restauraciones parciales sobre hueso de buena calidad son rehabilitadas con suaves contactos en céntrica.

Respecto a la selección de pacientes hay que valorar la relación riesgo-beneficio que supone la restauración inmediata. Damos más valor a la restauración funcional de una arcada totalmente edéntula y al mantenimiento de la estética de una prótesis unitaria o parcial en el sector anterior, que a la rehabilitación de los sectores posteriores de ambas arcadas.

\section{Discusión}

La carga inmediata de los implantes dentales es consecuencia de la evolución técnica y de la exigencia de un paciente que quiere reincorporarse lo más rápidamente posible a sus hábitos de vida. Algunos pacientes no toleran la prótesis removible o no se encuentran cómodos durante la masticación o el habla, o simplemente no desean esperar de 3 a 6 meses para la colocación de la prótesis fija.

Sólo hay publicados tres Ensayos Clínicos Aleatorizados (ECA) que comparen un protocolo de carga inmediata con el protocolo convencional. Dos de ellos se realizaron sobre sobredentaduras mandibulares en pacientes edéntulos y el ECA restante se realizó en pacientes edentulos parciales.

Chiapasco en 2001, con un diseño paralelo que incluía a diez pacientes en cada grupo, comparó 4 implantes Brånemark System (Nobel Biocare, Göteborg, Suecia) en localización interforaminal cargados inmediatamente mediante barra y sobredentadura en mandíbulas desdentadas con otros 4 cargados de forma convencional. Un implante fracasó en cada grupo y no hubo diferencias para el sexo, la edad y la longitud de los implantes usados. Considerando a los pacientes como unidad de análisis no hubo diferencias significativas entre ambos grupos. ${ }^{27}$ Romeo en 2002, en un ensayo similar con implantes ITI (ITI Dental Implant System, Institut Straumann, Waldenburg, Suiza) tampoco encontró diferencia entre las diferentes estrategias de carga un año después de la función. ${ }^{28}$

Romanos, en un diseño de boca dividida que incluyó 12 pacientes en cada grupo, comparó 3 implantes Ankylos (Ankylos Dental Implant Systems, Friadent, Mannheim, Alemania) distales a los caninos mandibulares cargados el mismo día con restauraciones temporales frente a 3 implantes en el lado contralateral cargados convencionalmente a los tres meses. Los pacientes fueron seguidos durante un año y ningún implante fracasó. No hubo diferencia estadísticamente significativa para los fracasos de la prótesis o del implante entre las diferentes estrategias de carga. ${ }^{29}$ gaps. The fixed provisional prosthesis in totally edentulous arches should have a proper distribution, but with limited central contact or maximum intercuspidation. Excursion contact should be eliminated from the restoration together with any contact in the molar region whenever possible. ${ }^{23}$ The role played by postoperative dietary recommendations has yet to be defined, together with that played by the opposing dentition type.

In provisional partial or single restoration, protrusive lateral excursive and premature contact should be avoided. But certain clinical situations result in provisional prostheses being subject to excursion contact if there is no centric occlusion. Single implants that do not have occlusal loading forces can be subject to secondary lateral loads around the food bolus. The skill of the prosthodontist in distributing the load between the natural teeth and the prostheses over the implant is fundamental. There is controversy as to whether they should remain completely out of the occlusion area for two to three months ${ }^{24,25}$ or if they can be restored in centric occlusion. Calandriello restored 50 molars with wide implants in centric occlusion without restricting the diet of the patients. ${ }^{26}$

In our opinion, we prefer to leave single restorations in the anterior sector load-free whenever possible. Premolars can be adjusted in occlusion so that there is no contact during protrusive movements and during lateral excursions. Partial restorations on good quality bone can be rehabilitated with smooth contact in centric occlusion.

With regard to patient choice, a risk-benefit assessment has to be made when considering immediate restoration. We give more value to functional restoration of a totally edentulous arch and to maintaining aesthetic appearances of a single or partial prostheses in the anterior sector, than to the rehabilitation of the posterior sections of both arches.

\section{Discussion}

Immediate loading of dental implants is a consequence of the technical evolution and the demands of patients that want to return to their usual routines as quickly as possible. Some patients do not tolerate removable prostheses, they may be uncomfortable during mastication or speech, or they simply do not want to wait three to six months for a fixed prosthesis to be placed.

There are only three Randomized Clinical Trials (RCT) that compare an immediate loading protocol with the conventional protocol. Two of them were carried out on mandibular overdentures in edentulous patients and the remaining $R C T$ was carried out in partially edentulous patients.

In 2001 Chiapasco carried out a parallel study that included ten patients in each group. He compared 4 Brånemark System implants (Nobel Biocare, Göteborg, Sweden) located in the interforaminal areas of edentulous mandibles, and which were immediately loaded with bars supporting overdentures, with 4 that were loaded conventionally. One 
A pesar de que no se ha publicado ningún Estudio Clínico Aleatorio (ECA) que compare carga inmediata y diferida en prótesis fija sobre mandíbulas edentulas existen estudios multicéntricos prospectivos de larga evolución con gran número de pacientes que permiten obtener conclusiones de indudable valor científico. Schnitman en 1990 comparaba implantes cargados de forma inmediata en la mandíbula, frente a implantes sumergidos en el mismo paciente que utilizaba de control. Comunicó que los implantes distales al agujero mentoniano eran más susceptibles de fallo y publicó las primeras recomendaciones para incrementar la supervivencia a largo plazo de los cargados de forma inmediata. La disminución del micromovimiento durante el periodo de remodelación ósea podía lograrse con el uso de una prótesis provisional atornillada con un perfecto ajuste pasivo que ferulizara todos los implantes. ${ }^{5}$

En 1999, Brånemark presentó el Novum System (Brånemark Novum, Nobel Biocare, Göteborg, Suecia) para carga inmediata. ${ }^{30}$ El sistema une tres implantes posicionados en la región anterior de la mandíbula, de $4 \mathrm{~mm}$ de diámetro y longitud mínima de $13 \mathrm{~mm}$, con una plataforma de titanio (infraestructura). Sobre ésta se atornilla una superestructura que porta la prótesis fija. Posteriormente Henry y cols . en un estudio multicéntrico que incluía 51 pacientes comunicaba una supervivencia acumulada del 91\% para los implantes y del $94 \%$ en la prótesis al año de seguimiento. ${ }^{31}$

En nuestra opinión la carga inmediata con sistemas protésicos prediseñados (estructuras de titanio prefabricadas) previo a la colocación de los implantes no ha resuelto todavía de forma eficaz el problema del ajuste pasivo de la prótesis, aumentando la posibilidad de exceso de micromovimiento y el consiguiente fallo biomecánico.

Cooper en 2002 en una serie de 10 pacientes a los que se les colocaron 5 implantes inmediatos en alvéolos postextracción entre ambos forámenes mentonianos para carga inmediata, comunicó una tasa de supervivencia del 100\%. Los autores concluían que la carga inmediata en alvéolos postextracción reciente tenía un elevado éxito. ${ }^{32}$

Wolfinger en 2003, en un estudio de 3 a 5 años de seguimiento con implantes Brånemark configuró dos grupos de tratamiento. El primer grupo era cargado con 6 implantes tanto en el sector anterior como posterior de la mandíbula. El segundo grupo era tratado con 10 implantes por mandíbula, cargando 4 de ellos con una prótesis provisional acrílica y dejando los 6 restantes sumergidos para descubrirlos en un segundo procedimiento. La supervivencia de los implantes cargados de forma inmediata del primer brazo del estudio fue del $97 \%$, mientras que del segundo fue del $80 \%$. Este estudio evidencia la ineficiencia de sumergir implantes de rescate protésico en vez de dar más estabilidad a la prótesis provisional con un número adecuado de ellos. ${ }^{33}$

Maló en 2003, presentó un estudio retrospectivo posicionando 4 implantes Brånemark interforaminales en 44 pacientes. Demostró la eficacia del uso de implantes angulados a $45^{\circ}$ colocados próximos al foramen mentoniano para obtener una posición más distal de la superestructura sin comprometer el nervio alveolar inferior. La tasa acumulativa de supervivencia con un seguimiento de 1 a 3 años fue del 96,7\% y la supervivencia de la prótesis del $100 \% .34$ implant failed in each group and there was no difference between sexes, age and implant length. The patients were considered as a unit in the analysis and there were no significant differences between both groups. ${ }^{27}$ In 2002, Romeo in a similar study with ITI implants (ITI Dental Implant System, Institut Straumann, Waldenburg, Switzerland) failed to find any differences between loading strategies a year after being brought into function. ${ }^{28}$

In a split mouth study, Romanos included 12 patients in each group, and 3 Ankylos implants (Ankylos Dental Implant Systems, Friadent, Mannheim, Germany) that were distal to the mandibular canines and loaded on the same day with temporary restorations, were compared with 3 implants on the contralateral side that were loaded conventionally three months later. The patients were followed for a year and none of the implants failed. There was no difference that was statistically significant with regard to prostheses or implant failure between the different loading strategies. ${ }^{29}$

In spite of the fact that no Randomized Clinical Trials $(R C T)$ have been published that compare immediate and delayed loading of fixed prostheses over edentulous mandibles, there are prospective long-term multicentric studies with a large number of patients that allow conclusions to be made with undoubted scientific value.

In 1990 Schnitman compared implants that were loaded immediately in the mandible, with implants that were submerged in the same patient who was then used as a control source. He reported that the implants that were distal to the mental foramen were more susceptible to failure and he published the first recommendations for increasing long-term survival of immediately loading implants. Decreases in micromovements during the bone remodelation period could be achieved by using a provisional threaded prosthesis screwed with a perfect passive adjustment that splinted together all the implants. ${ }^{5}$

In 1999 Brånemark presented the Novum System (Brånemark Novum, Nobel Biocare, Göteborg, Sweden) for immediate loading. 30 The system united three implants that were positioned in the anterior region of the mandible, with a diameter of $4 \mathrm{~mm}$ and a minimum length of $13 \mathrm{~mm}$, with a titanium platform (infrastructure). On this a superstructure was screwed that had the fixed prosthesis. Later, Henry el al, in a multicentric study that included 51 patients, reported an accumulated survival rate of $91 \%$ for implants and 94\% for prostheses after a follow-up of one year. ${ }^{31}$

In our opinion, immediate loading with pre-designed prosthetic systems (prefabricated titanium structures) before implant placement has not resolved the problem efficiently of passive prosthesis adjustment. The possibility of excessive micromovement is increased leading to the resulting biomechanical failure.

In 2002 Cooper published a series of 10 patients that were fitted with 5 immediately loading implants in extraction sockets between both mental foramina that were immediately loaded, and he reported a survival rate of $100 \%$. The 
Testori en 2004, publicó el primer estudio prospectivo multicéntrico en implantes Osseotite (3i, Implant Inovations, West Palm Breach, FL, EE.UU.) sobre carga inmediata mandibular de 62 pacientes con 5 implantes interforaminales para soportar una prótesis híbrida provisional con extensiones en oclusión completa. Mostró una tasa acumulativa de supervivencia del 99,4\% a los dos años, sin cambios significativos en el hueso marginal. ${ }^{35}$

Los datos obtenidos sugieren que las tasas de supervivencia de los implantes cargados de forma inmediata para reha-

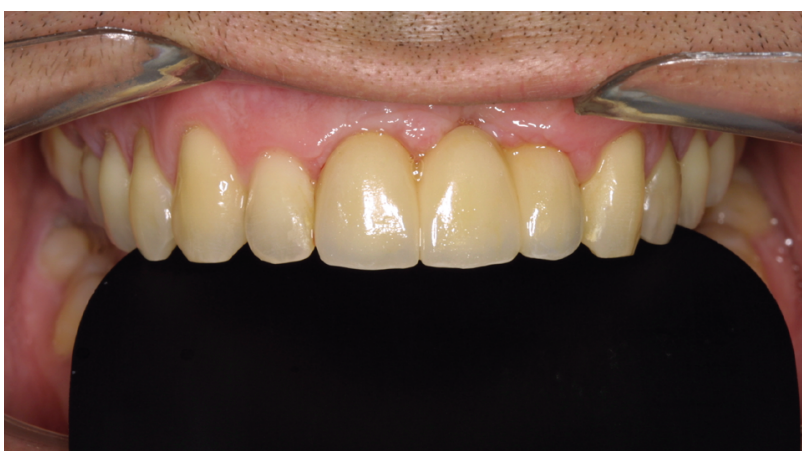

Figura 5. Prótesis definitiva metalcerámica. La conservación del tejido blando es crítica para obtener buenos resultados.

Figure 5. Definitive metal-ceramic prosthesis. The conservation of soft tissue is critical for obtaining good results. bilitar mandíbulas totalmente edéntulas con prótesis fija (media de 95\%) son comparables a las obtenidas con el protocolo convencional. Esto es achacable a la buena calidad ósea de la región que asegura una estabilidad primaria suficiente.

En nuestro Servicio la carga inmediata con prótesis fija en mandíbulas edéntulas se realiza de forma rutinaria. El número de implantes colocados varía de 4 a 6 en función del grado de reabsorción ósea. Utilizando 4 ó 5 implantes entre ambos orificios mentonianos en mandíbulas con reabsorción del sector posterior. En casos con volumen óseo suficiente distal a la salida del nervio dentario inferior utilizamos 6 implantes distribuidos en la posición del incisivo lateral, primer premolar y primer molar. Usamos implantes roscados con superficie tratada de 3,75 ó $4 \mathrm{~mm}$ de diámetro de la mayor longitud posible sin llegar al anclaje bicortical. Cargamos todos los implantes que logren estabilidad rotacional a un torque de cómo mínimo $30 \mathrm{Ncm}$ de inserción. No realizamos mediciones de la frecuencia de resonancia de forma habitual.

Hasta la fecha no hay publicados ningun ECA sobre carga inmediata de prótesis fija en maxilares edéntulos pero en un nivel más bajo de evidencia científica hayamos series de casos o cohortes prospectivas que dan una valiosa información sobre este procedimiento.

La primera serie fue publicada por Tarnow en 1997 e incluía sólo 4 pacientes con una supervivencia del $100 \%$ de los implantes y las prótesis. ${ }^{36}$ Posteriormente, diferentes autores, ${ }^{37-39}$ han publicado pequeñas series con supervivencia de los implantes que varían del 87,5 al $100 \%$ y con éxito de la prótesis del 96,5 al 100\%. Balshi en 2005, aporta una serie consecutiva de 55 pacientes con al menos 1 año de seguimiento en la que 10 implantes Brånemark son colocados en el maxilar edéntulo para sustentar una prótesis fija provisional acrílica. La supervivencia de los implantes fue del $99 \%$ con un éxito en la prótesis del $100 \% .40$

Nuestro grupo utiliza de forma predecible este procedimiento en pacientes seleccionados con volumen óseo adecuado, sin graves discrepancias máxilo-mandibulares en el plano vertical y anteroposterior; Caso 2 (Figs. 5-10). Utilizamos entre 6 y 8 implantes roscados, con superficie rugosa distribuidos lo más equidistantemente posible en la arcada. Con 4 ó 3,75 mm de diámetro y de la mayor longitud posible, con una altura mínima de $10 \mathrm{~mm}$. Usamos anclaje bicortical en el suelo de la fosa nasal y en los senos authors concluded that immediate loading in recent extraction sockets had a high success rate. ${ }^{32}$

In 2003 Wolfinger created two treatment groups in a study using Brånemark implants that had a 3 to 5 year follow-up. The first group was loaded with 6 implants in the anterior portion as well as the posterior portion of the mandible. The second group was treated with 10 implants per mandible, 4 of which were loaded with a provisional acrylic prosthesis and the remaining 6 were submerged and uncovered in a second procedure. The survival of the immediately loading implants in the first branch of the study was $97 \%$, while in the second it was $80 \%$. This study showed the inefficiency of submerging prosthetic salvage implants instead of providing more stability to the provisional prosthesis by having an adequate number. ${ }^{33}$

In 2003 Malo presented a retrospective study in which 4 interforaminal Brånemark implants were placed in 44 patients. He demonstrated the efficiency behind using angulated abutments at 45 degrees by the mental foramen in order to obtain a more distal position of the superstructure without compromising the lower alveolar nerve. The accumulative survival rate after a follow-up of 1 to 3 years was $96.7 \%$ and prosthetic survival was $100 \% .^{34}$

In 2004 Testori published the first prospective multicentric study with Osseotite implants (3i, Implant Innovations, West Palm Beach, FL, USA) for immediate mandibular loading in 62 patients with 5 interforaminal implants in order to support a provisional hybrid prosthesis with extensions in complete occlusion. He reported an accumulative survival rate of $99.4 \%$ two years later, with no significant changes in marginal bone. ${ }^{35}$

The data obtained suggest that the survival rate of the implants that were immediately loaded in order to rehabilitate totally edentulous lower jaws with a fixed prosthesis (mean 95\%) is comparable to that obtained through the conventional protocol. This has been attributed to good bone quality in the region that ensures sufficient primary stability.

In our service the immediate load approach using a fixed prosthesis for edentulous mandibles is carried out in a routine fashion. The number of implants placed varies between 4 and 6 according to the degree of bone resorption. We use 4 to 5 implants between both mental orifices of the lower jaw with resorption in the posterior sector. In cases with sufficient bone volume that is distal to where the inferior dental nerve appears, we use 6 implants around the lateral 
maxilares y protocolos de fresado para hueso blando con el propósito de aumentar la estabilidad primaria. Sólo se cargan los implantes con estabilidad rotacional y un valor ISQ mayor de 55 .

En pacientes parcialmente edéntulos, además del ECA mencionado anteriormente existen ensayos publicados que permiten sacar algunas conclusiones prácticas. Rocci y cols. comparaba dos grupos de 22 pacientes que había cargado con implantes con superficie tratada con oxidación anódica para rehabilitar edentulismos parciales en la región posterior de la mandíbula frente a implantes mecanizados. Después de 1 año de carga presentaba una supervivencia del 95,5\% de los implantes con superficie rugosa frente al 85,5\% de los implantes con superficie mecanizada. En ambos grupos el fallo de la osteointegración estaba relacionado con hueso de baja densidad y pacientes fumadores. ${ }^{41}$ Glauser y cols., en una serie de casos clínicos comunicaba un 97,1\% de éxito usando la misma superficie (Brånemark System Mk IV TiUnite, Nobel Biocare AB, Gothenburg, Suecia) en prótesis unitarias y parciales en hueso predominantemente blando. ${ }^{42}$

Respecto a los implantes unitarios, Hui en 2001, en una serie prospectiva de 24 pacientes en la que colocaba implantes Brånemark inmediatos a la extracción de un diente unitario en la zona anterior del maxilar con un torque de $40 \mathrm{Ncm}$. comunicaba un $100 \%$ de supervivencia al año dejando las restauraciones provisionales fuera de oclusión. ${ }^{3}$ Drago en 2004, en una serie similar de 93 pacientes con implantes Osseotite unitarios fuera de oclusión comunicaba un $97,4 \%$ de supervivencia. ${ }^{44}$ Ericsson, en un ensayo sobre implantes unitarios en posiciones anteriores a los molares comparaba un grupo de 14 pacientes frente a otro control del 8 . No tuvo fracasos utilizando fijaciones de al menos $13 \mathrm{~mm}$ de longitud y 3,75 $\mathrm{mm}$ de diámetro. ${ }^{45}$

Abboud en 2005, comunicaba el éxito de una serie de 20 pacientes con implantes unitarios en la región molar de la mandíbula y el maxilar con ligera oclusión en máxima intercuspida-

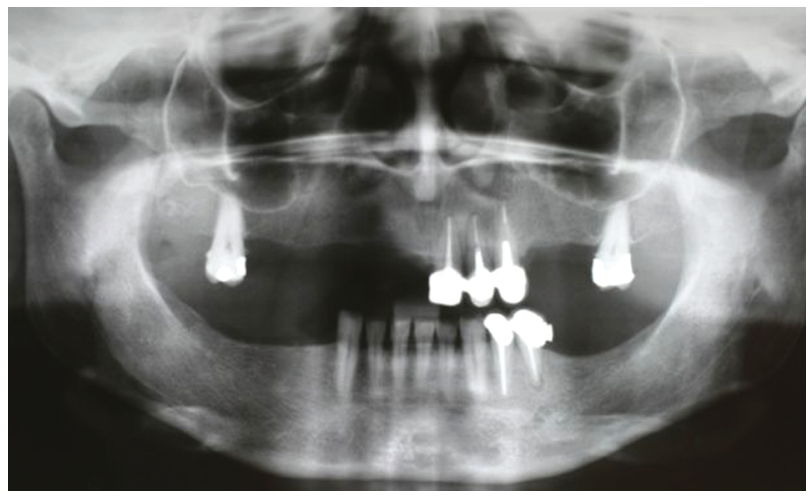

Figura 6. Radiografía preoperatoria de una paciente desdentada parcial previa a una rehabilitación completa de la arcada superior. Figure 6. Preoperative radiography of a partially edentulous patient before a complete rehabilitation of the upper arch.

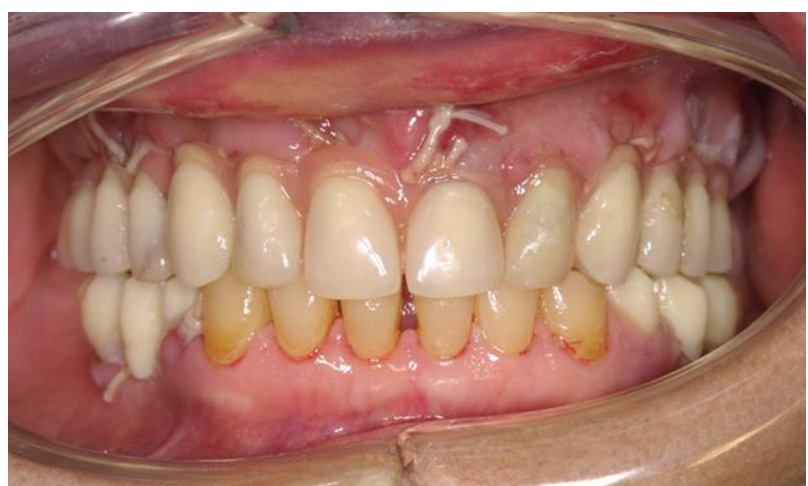

Figura 7. Prótesis provisional implantosoportada sobre 6 implantes roscados de $4 \times 13 \mathrm{~mm}$ colocada a las 48 horas de la colocación de los implantes. Se realizó toma de impresiones, prueba de rodillo y prueba de dientes en cera de forma convencional.

Figure 7. Provisional implant-supported prosthesis on 6 threaded implants measuring $4 \times 13 \mathrm{~mm}$ placed 48 hours of implant placement. The taking of impressions, roller test and wax-up was carried out conventionally.

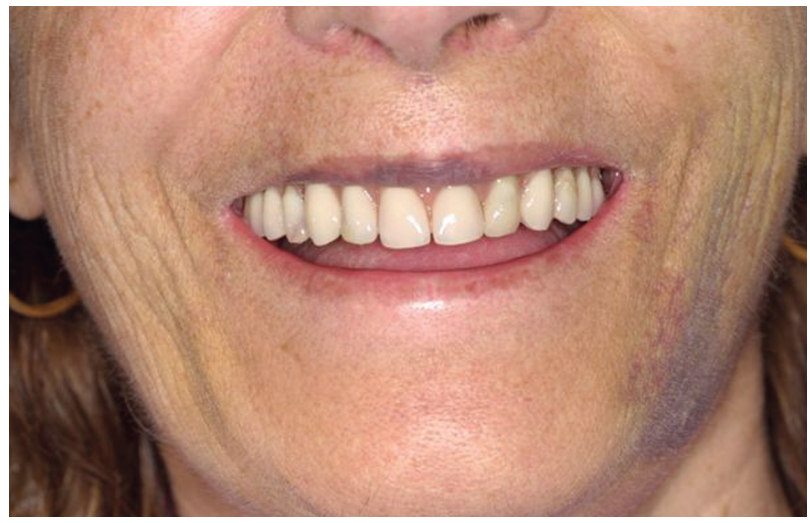

Figura 8. La comodidad para el paciente de una prótesis implantosoportada colocada de forma inmediata no es comparable a las prótesis removibles.

Figure 8. The comfort for the patient of an immediately loaded implantsupported prosthesis cannot be compared to that of a removable prosthesis. incisor, first premolar and first molar. We use threaded implants with a treated coating and a diameter of 3.75 to $4 \mathrm{~mm}$ that have the longest possible length without reaching the bicortical anchorage. We load all the implants that have rotational stability with a torque that has a minimum insertion of $30 \mathrm{Ncm}$. We do not carry out resonance frequency measurements as a matter of practice.

To date there is no RCT published on immediate loading of fixed prostheses for edentulous maxillas, but on a lower scale of scientific proof we have found prospective series of cases or cohorts that provide very valuable information on this procedure.

The first series was published by Tarnow in 1997 and it included only 4 patients. The implant and prostheses survival rate was $100 \% .{ }^{36}$ Later different authors ${ }^{37-39}$ published small series with implant survival rates that varied between 87.5 and $100 \%$, and with prosthesis success rates between 96.5 and $100 \%$. In 2005 Balshi reported a consecutive series of 55 patients that were followed for at least one year. Ten Brånemark implants were placed in each edentulous maxilla in order to support an acrylic fixed provisional prosthesis. The implant survival rate was $99 \%$ and the prosthetic success rate was $100 \% .40$

Our group uses this procedure in a predictable fashion in selected patients with adequate bone volume, without serious maxillo-mandibular discrepancies in the vertical and antero-posterior axis. Case 2 (Figs. 5-10) We use 
ción. ${ }^{46}$ Calandriello incluía en su estudio sobre carga de molares mandibulares con implantes anchos con superficie TiUnite a 44 pacientes y 50 implantes rehabilitados con coronas provisionales en oclusión céntrica, el estudio ofrecía un seguimiento medio de sólo 6 meses sin pérdida de implantes. ${ }^{26}$

En nuestro protocolo utilizamos habitualmente un implante por cada diente que vayamos a sustituir si el espacio protésico, el volumen óseo y la distancia biológica entre implantes y entre éstos y los dientes adyacentes es la adecuada. En el caso de dientes unitarios utilizaremos el implante más largo que nos permita la anatomía con el fin de lograr una relación corona-raíz favorable, si fuera posible mayor de $12 \mathrm{~mm}$. En el sector anterior tanto los tejidos blandos como el hueso disponible debe ser ideal para aplicar esta técnica; Caso 3 (Figs. 11-13). En los casos de implante inmediato a la extracción con una arquitectura ósea y papilar conservadas preferimos la cirugía sin colgajo. Evitamos el colapso de las partes blandas y preservar la estructura de la papila con la restauración provisional. No desperiostizar el hueso alveolar limita la reabsorción ósea en el cuello del implante.

Los estudios clínicos indican de forma clara y evidente la posibilidad de osteointegración tras la colocación del implante en una sola fase quirúrgica y su carga oclusal inmediata. Los resultados publicados indican que la supervivencia de los implantes con el protocolo inicialmente definido por Brånemark puede ser usada como estándar de comparación frente a la carga inmediata. Aunque existen pocos estudios a largo plazo que comparen de forma efectiva este método con la técnica convencional la única duda que existe respecto a la carga inmediata es si ésta condiciona un mayor porcentaje de pérdidas tempranas de los implantes. Un razonamiento lógico nos lleva a pensar que una vez el implante se integra su comportamiento es independiente del tiempo en el que fue realizada la carga. Una vez osteointegrados los implantes, su comportamiento es idéntico a los implantes cargados de forma diferida y las pérdidas tardías serían causadas por la disminución progresiva de los contactos hueso-implante después

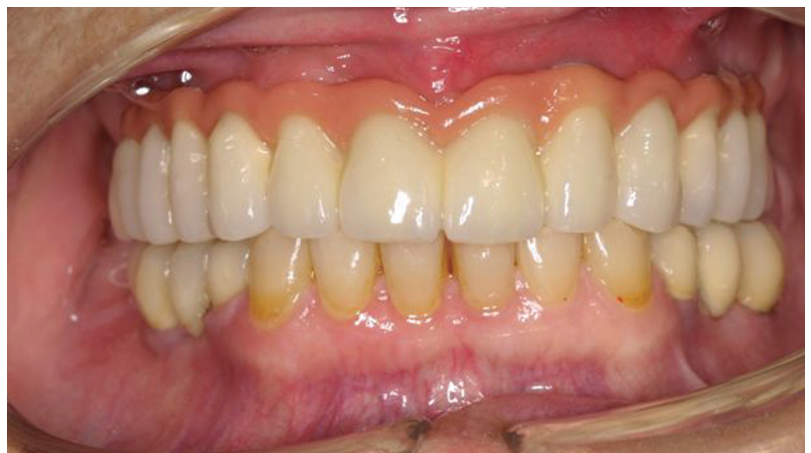

Figura 9. La prótesis definitiva metal cerámica se coloca a partir de los 3 meses desde la colocación de los implantes.

Figure 9. The definitive metal-ceramic prosthesis is placed 3 months after the placement of implants.

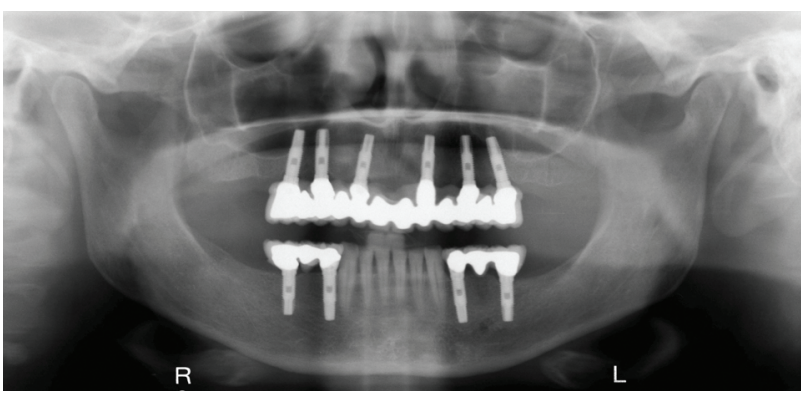

Figura 10. La imagen radiológica no muestra pérdida osea periimplantaria en ninguno de los implantes una vez conseguida la osteointegración secundaria.

Figure 10. The radiologic image shows no peri-implant bone loss in any of the implants once secondary osseointegration is achieved.

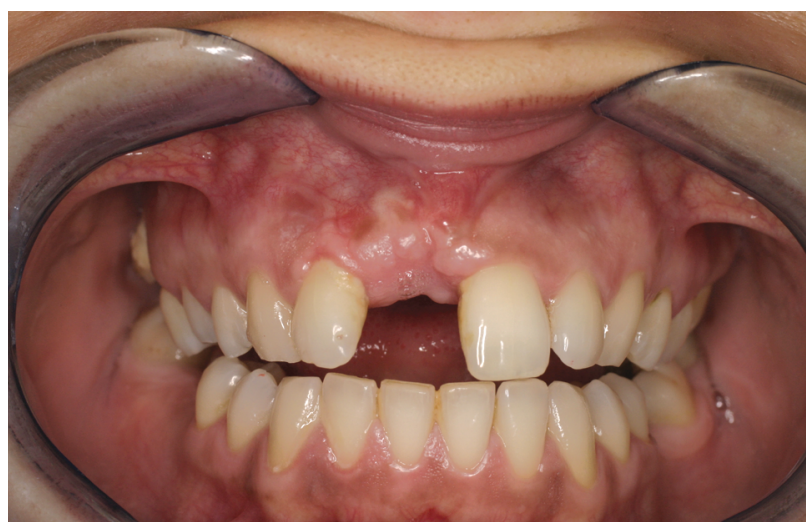

Figura 11. La pérdida de un incisivo central superior es una de las más claras indicaciones para realizar una carga inmediata.

Figure 11. The loss of an upper central incisor is one of the clear indications for immediate loading. between 6 and 8 threaded implants with a rough surface that are distributed using the most equidistant points possible in the arch. They have a diameter of 4 or $3.75 \mathrm{~mm}$ and the longest length possible, and a minimum height of $10 \mathrm{~mm}$. We use bicortical anchorage on the nasal floor and in the maxillary sinuses and drilling protocols for soft bone with the aim of increasing primary stability. Only implants with a rotational stability and an ISQ value greater than 55 are loaded. In partially edentulous patients, in addition to the RCT previously mentioned, there are trials published that permit extracting certain practical conclusions. Rocci et al. compared two groups of 22 patients that were loaded with implants treated with anodic oxidation in order to rehabilitate partially edentulous patients in the posterior part of the mandible, with mechanical implants. After being loaded for one year, the implants with rough surfaces had a survival rate of $95.5 \%$ as opposed to those with a machined surface that had a survival rate of $85.5 \%$. In both groups osseointegration failure was related with lowdensity bone and smokers. ${ }^{41}$ Glauser y cols. reported a series of clinical cases with a $97.1 \%$ success rate in which the same surface (Brånemark System Mk IV TiUnite, Nobel Biocare $A B$, Gothenburg, Sweden) had been used for partial and single-tooth prostheses in bone that was predominantly soft. ${ }^{42}$

With regard to single-tooth implant, in a prospective series of 24 patients in 2001 Hui placed Brånemark implants immediately after single-tooth extractions in the anterior region of the maxilla with a 40 $\mathrm{Ncm}$ torque. He reported a $100 \%$ survival rate after one year 
de la rehabilitación prostodóncica. Por ello consideramos que cualquier estudio sobre esta técnica no necesita de periodos de seguimiento superiores al año para validar su fiabilidad.

Desde el punto de vista metodológico, el mayor problema viene determinado no por el tiempo de seguimiento de los pacientes sino por los problemas de diseño de los estudios. El posible riesgo de selección al no definir con claridad los procedimientos de ocultamiento de la asignación aleatoria, pueden tender a cargar de forma inmediata los implantes colocados en los casos más favorables lo que sobreestimaría los efectos del tratamiento.

La relación del riesgo-beneficio debe ser evaluada para cada caso de forma individual. En un extremo tendríamos los pacientes totalmente edéntulos que no toleran una prótesis removible y en otro extremo los pacientes a los que se le han colocado implantes a partir del segundo premolar para rehabilitaciones parciales. La situación de mayor riesgo biomecánico es sin duda la colocación de un implante unitario en el sector posterior del maxilar, puesto que difícilmente puede ser aumentado el número de implantes colocados y la longitud del mismo suele ser escasa. Cuando el reemplazo dentario se realiza de forma inmediata en zonas no estéticas el beneficio obtenido es mínimo. ${ }^{18}$

Restauración inmediata no significa necesariamente carga inmediata a la más alta magnitud que puede desarrollar en aparato masticador. Un abordaje conservador en el diseño de la prótesis disminuye el estrés al que es sometido el implante aumentando el porcentaje de éxito. En pacientes parcialmente edéntulos la colocación de una restauración inmediata no implica necesariamente carga oclusal durante las primeras semanas de curación ósea. En estos casos la estética prima sobre la función que realiza la prótesis provisional.

\section{Conclusiones}

Las literatura existente hasta el momento y la experiencia de los autores demuestra que la carga inmediata es un procedimiento fiable siempre que se realice una selección previa de los pacientes que van a ser tratados. Los indudables beneficios consisten en la no necesidad de prótesis removible, evitar la segunda fase quirúrgica, preservación de los tejidos blandos y una mayor comodidad para el paciente, con el único argumento en contra de un teórico incremento en el fracaso de los implantes no demostrado hasta el momento en leaving provisional restorations without occlusion. 43 In 2004 Drago in a similar series of 93 patients with Osseotite single-tooth implants out of occlusion, reported a $97.4 \%$ survival rate. ${ }^{44}$ Ericsson, in a trial on single-tooth restorations that had an anterior position to the molars, compared a group of 14 patients against a control group of 8 . No failures were reported with fixtures having a length of at least $13 \mathrm{~mm}$ and a diameter of $3.75 \mathrm{~mm}$. 45

Abboud in 2005 reported a successful series of 20 patients that were restored with single-tooth implants in the molar region of the mandible and the maxilla with slight occlusion and maximum intercuspidation. ${ }^{46}$ Calandriello, in his study on the loading of mandibular molars with wide implants with a TiUnite surface, included 44 patients and 50 implants, that were rehabilitated with provisional crowns in centric occlusion. The follow-up was of only 6 months and no implants were lost. ${ }^{26}$

In our protocol we normally use one implant per tooth to be replaced providing the prosthetic space, bone volume and biological distance between implants and the former, and adjacent teeth is sufficient. In the case of single teeth we use the longer implants, which anatomically permit achieving a more favorable crown-root relationship, that are greater if possible than $12 \mathrm{~mm}$.

In the anterior region, soft tissue as well as the available bone should be ideal for applying this technique. Case 3 (Figs. 11-13) In cases of extraction followed by an immediate implant, and when bone and papillary architecture have been conserved, we prefer flap-free surgery. Soft-tissue collapse should be avoided and the structure of the papilla should be preserved by means of a provisional restoration. If the periosteum is not released from the alveolar bone, bone absorption is limited to the neck of the implant.

Clinical studies indicate clearly that osseointegration is possible following the placement of implants in a single surgical phase with immediate occlusal loading. The results published indicate that the survival of the implants with the pro- 
los ensayos realizados. Para los autores, los mayores inconvenientes que presentan los procedimientos de carga inmediata son debidos a la necesidad de una adecuada coordinación quirúrgico - prostodóncica. Finalmente, concluimos que aunque hubiera una mayor tasa de fracaso de los implantes en la carga inmediata, ésta puede ser asumida por el paciente y el cirujano. Los beneficios de la técnica en casos totalmente edéntulos o zonas de alta exigencia estética superan al inconveniente de la pérdida de algún implante, porque el paciente ha podido disfrutar de las ventajas de una dentición fija desde el primer momento. En estos casos, la pérdida de algún implante raramente compromete el éxito de la prótesis provisional.

\section{Bibliografía}

1. Brunski JB, Moccia AF Jr, Pollack SR, Korostoff E, Trachtenberg DI. The influence of functional use of endosseous dental implants on the tissue-implant interface. I. Histological aspects. J Dent Res 1979; 58:1953-69.

2. Buser D, Mericske-Stern R, Bernard JP, Behneke A, Behneke N, Hirt HP, Belser UC, Lang NP. Long-term evaluation of non-submerged ITI implants. Part 1: 8year life table analysis of a prospective multi-center study with 2359 implants. Clin Oral Implants Res 1997;8:161-72.

3. Cochran DL, Buser D, Ten Bruggenkate CM, Weingart D, Taylor TM, Bernard JP, Peters F, Simpson JP. The use of reduced healing times on ITI implants with a sandblasted and acid-etched (SLA) surface: early results from clinical trials on ITI SLA implants. Clin Oral Implants Res 2002;13:144-53.

4. Lederman PD. Stegpprothetische Versorgung des zahnlosen Unterkiefers mit Hilfe plasmabeschichteten Titanschraubimplantaten. Destsche Zahnärztlische Zeitung 1979;34:907-11.

5. Schnitman PA, Wohrle PS, Rubenstein JE. Immediate fixed interim prostheses supported by two-stage threaded implants: methodology and results. / Oral Implantol 1990;16:96-105.

6. Friberg B, Sennerby L, Linden B, Grondahl K, Lekholm U. Stability measurements of one-stage Branemark implants during healing in mandibles. A clinical resonance frequency analysis study. Int J Oral Maxillofac Surg 1999;28:266-72.

7. Glauser R, Sennerby L, Meredith N, Ree A, Lundgren A, Gottlow J, Hammerle $\mathrm{CH}$. Resonance frequency analysis of implants subjected to immediate or early functional occlusal loading. Successful vs. failing implants. Clin Oral Implants Res 2004;15:428-34.

8. Piattelli A, Corigliano M, Scarano A, Quaranta M. Bone reactions to early occlusal loading of two-stage titanium plasma-sprayed implants: a pilot study in monkeys. Int J Periodontics Restorative Dent 1997;17:162-9.

9. Szmukler-Moncler S, Salama H, Reingewirtz Y, Dubruille JH. Timing of loading and effect of micromotion on bone-dental implant interface: review of experimental literature. J Biomed Mater Res 1998;43:192-203.

10. Albrektsson T, Branemark PI, Hansson HA, Lindstrom J. Osseointegrated titanium implants. Requirements for ensuring a long-lasting, direct bone-to-implant anchorage in man. Acta Orthop Scand 1981;52:155-70.

11. Johansson B, Strid KG. Assessment of bone quality from cutting resistance during implant surgery. Int J Oral Maxillofac Implants 1994;6:164-171.

12. Meredith N, Alleyne D, Cawley P. Quantitative determination of the stability of the implant-tissue interface using resonance frequency analysis. Clin Oral Implants Res 1996;7:261-7.

13. Meredith N. Assessment of implant stability as a prognostic determinant. Int J Prosthodont 1998; 11:491-501. tocol initially defined by Brånemark can be used as a standard for comparing immediate loading. Although there are no long term studies that effectively compare this method with conventional techniques, the only remaining question with regard to immediate loading, is whether this leads to a greater percentage of early implant loss. Logical reasoning leads us to believe that once integrated, the behavior of the implant is independent of the loading time. Once osseointegration has taken place, the behavior of the implants is the same as that of delayed loading implants, and later losses would be due to the progressive decrease in bone-implant contact after prosthodontic rehabilitation. We therefore consider that study follow-ups of over a year are unnecessary for establishing whether the technique is reliable or not.

From the point of view of methodology, the greatest problem is not patient following but study design. The possible risk on selection, if the procedure in the randomized concealment of allocation is not clearly defined, can tend towards the immediate loading of the implants in the more favorable cases, which would overestimate the effect of the treatment.

The risk-benefit relationship should be evaluated in each case individually. In one extreme there would be the totally edentulous patient that do not tolerate a removable prosthesis, and in the other there would be the patients with implants as from the second premolar in partial rehabilitations. The situation with the greatest biomechanical risk is without doubt placing a single implant at the back of the maxilla, as the number of implants placed cannot be easily increased and the length involved is short. When dental replacement is carried out immediately in areas that are not aesthetically important, the benefit obtained is minimum. ${ }^{18}$

Immediate restoration does not necessarily mean immediate loading to the greatest magnitude that the masticatory apparatus can develop. A conservative approach in the design of the prosthesis reduces the stress that the implant is subjected to, and the success rate increases. In partially edentulous patients, carrying out an immediate restoration does not necessarily imply occlusal loading during the first weeks of bone healing. In these cases the aesthetic appearance is more important than the function carried out by the provisional prosthesis.

\section{Conclusions}

The literature that exists up to now, together with the experience of the authors, shows that immediate loading is a reliable procedure, providing a selection is made previously of the patients to be treated. Without any doubt the advantages consist in removable prostheses being unnecessary, together with two-stage surgery. Soft tissue is preserved and there is greater comfort for the patient. The only argument against a theoretical increase in the failure of implants has not been demonstrated in the trials carried out to date. For the authors the greatest inconvenience of the 
14. Esposito M, Coulthard P, Thomsen P, Worthington HV. The role of implant surface modifications, shape and material on the success of osseointegrated dental implants. A Cochrane systematic review. Eur J Prosthodont Restor Dent 2005;13:15-31.

15. Misch CE, Dietsh-Misch F, Hoar J, Beck G, Hazen R, Misch CM. A bone qualitybased implant system: first year of prosthetic loading. I Oral Implantol 1999;25:185-97.

16. Meyer U, Vollmer D, Runte C, Bourauel C, Joos U. Bone loading pattern around implants in average and atrophic edentulous maxillae: a finite-element analysis. J Craniomaxillofac Surg 2001;29:100-5.

17. Friberg B, Jisander S, Widmark G, Lundgren A, Ivanoff CJ, Sennerby L, Thoren C. One-year prospective three-center study comparing the outcome of a "soft bone implant" (prototype Mk IV) and the standard Branemark implant. Clin Implant Dent Relat Res 2003;5:71-7.

18. Misch CE, Hahn J, Judy KW, Lemons JE, Linkow LI, Lozada JL, Mills E, Misch CM, Salama H, Sharawy M, Testori T, Wang HL. Workshop guidelines on immediate loading in implant dentistry. J Oral Implantol 2004;30:283-8.

19. Esposito M, Hirsch JM, Lekholm U, Thomsen P. Biological factors contributing to failures of osseointegrated oral implants. (I). Success criteria and epidemiology. Eur J Oral Sci 1998;106:527-51.

20. Haider R, Watzek G, Plenk H Effects of drill cooling and bone structure on IMZ implant fixation. Int J Oral Maxillofac Implants 1993;8:83-91.

21. Aparicio C, Rangert B, Sennerby L. Immediate/early loading of dental implants: a report from the Sociedad Espanola de Implantes World Congress consensus meeting in Barcelona, Spain, 2002. Clin Implant Dent Relat Res 2003;5:57. 60 .

22. Lobbezoo F, Brouwers JE, Cune MS, Naeije M. Dental implants in tooth grinders. Ned Tijdschr Tandheelkd 2004;111:85-90.

23. Morton D, Jaffin R, Weber HP. Immediate restoration and loading of dental implants: clinical considerations and protocols. Int J Oral Maxillofac Implants 2004;19(Suppl):103-8.

24. Randow K, Ericsson I, Nilner K, Petersson A, Glantz PO. Immediate functional loading of Branemark dental implants. An 18-month clinical follow-up study. Clin Oral Implants Res 1999;10:8-15.

25. Ericsson I, Nilson H, Lindh T, Nilner K, Randow K. Immediate functional loading of Branemark single tooth implants. An 18 months' clinical pilot follow-up study. Clin Oral Implants Res 2000;11:26-33.

26. Calandriello R, Tomatis M, Vallone R, Rangert B, Gottlow J. Immediate occlusal loading of single lower molars using Branemark System Wide-Platform TiUnite implants: an interim report of a prospective open-ended clinical multicenter study. Clin Implant Dent Relat Res 2003;5(Suppl1):74-80.

27. Chiapasco M, Abati S, Romeo E, Vogel G. Implant-retained mandibular overdentures with Branemark System MKII implants: a prospective comparative study between delayed and immediate loading. Int / Oral Maxillofac Implants 2001; 16:537-46.

28. Romeo E, Chiapasco M, Ghisolfi M, Vogel G. Long-term clinical effectiveness of oral implants in the treatment of partial edentulism. Seven-year life table analysis of a prospective study with ITI dental implants system used for singletooth restorations. Clin Oral Implants Res 2002;13:133-43.

29. Romanos GE. Present status of immediate loading of oral implants. J Oral Implantol 2004;30:189-97.

30. Branemark PI, Engstrand P, Ohrnell LO, Grondahl K, Nilsson P, Hagberg K, Darle C, Lekholm U. Branemark Novum: a new treatment concept for rehabilitation of the edentulous mandible. Preliminary results from a prospective clinical followup study. Clin Implant Dent Relat Res 1999;1:2-16. procedure is due to the need for adequate surgical-prosthodontic coordination. Finally, we conclude that although there may be a greater risk of implant failure in immediate loading, this can be accepted by the patient and the surgeon. The advantages of the technique in totally edentulous cases, or in areas with high aesthetic requirements, far outweigh the inconveniences of the loss of an implant, because the patient has been able to enjoy the advantages of fixed dentition from the beginning. In these cases, the loss of an implant rarely compromises the success of the provisional prosthesis. 
31. Henry PJ, van Steenberghe D, Blomback U, Polizzi G, Rosenberg R, Urgell JP, Wendelhag. Prospective multicenter study on immediate rehabilitation of edentulous lower jaws according to the Branemark Novum protocol. Clin Implant Dent Relat Res 2003;5:137-42.

32. Cooper LF, Rahman A, Moriarty J, Chaffee N, Sacco D. Immediate mandibular rehabilitation with endosseous implants: simultaneous extraction, implant placement, and loading. Int J Oral Maxillofac Implants 2002;17:517-25.

33. Wolfinger GJ, Balshi TJ, Rangert B. Immediate functional loading of Branemark system implants in edentulous mandibles: clinical report of the results of developmental and simplified protocols. Int J Oral Maxillofac Implants 2003;18:250-7.

34. Malo P, Rangert B, Nobre M. "All-on-Four" immediate-function concept with Branemark System implants for completely edentulous mandibles: a retrospective clinical study. Clin Implant Dent Relat Res 2003;5(Suppl. 1):2-9.

35. Testori T, Del Fabbro M, Galli F, Francetti L, Taschieri S, Weinstein R. Immediate occlusal loading the same day or the after implant placement: comparison of 2 different time frames in total edentulous lower jaws. J Oral Implantol 2004;30:307-13.

36. Tarnow DP, Emtiaz S, Classi A. Immediate loading of threaded implants at stage 1 surgery in edentulous arches: ten consecutive case reports with 1- to 5-year data. Int J Oral Maxillofac Implants 1997;12:319-24.

37. Horiuchi K, Uchida H, Yamamoto K, Sugimura M. Immediate loading of Branemark system implants following placement in edentulous patients: a clinical report. Int J Oral Maxillofac Implants 2000;15:824-30.

38. Grunder U. Immediate functional loading of immediate implants in edentulous arches: two-year results. Int J Periodontics Restorative Dent 2001;21:545-51.
39. Misch CE, Degidi M. Five-year prospective study of immediate/early loading of fixed prostheses in completely edentulous jaws with a bone quality-based implant system. Clin Implant Dent Relat Res 2003;5:1728.

40. Balshi SF, Wolfinger G], Balshi TJ. A prospective study of immediate functional loading, following the Teeth in a Day protocol: a case series of 55 consecutive edentulous maxillas. Clin Implant Dent Relat Res 2005; 7:24-31.

41. Rocci A, Martignoni M, Gottlow J. Immediate loading of Branemark System TiUnite and machined-surface implants in the posterior mandible: a randomized open-ended clinical trial. Clin Implant Dent Relat Res 2003;5(Suppl. 1):57-63.

42. Glauser R, Lundgren AK, Gottlow J, Sennerby L, Portmann M, Ruhstaller $\mathrm{P}$, Hammerle $\mathrm{CH}$. Immediate occlusal loading of Branemark TiUnite implants placed predominantly in soft bone: 1-year results of a prospective clinical study. Clin Implant Dent Relat Res 2003;5(Suppl. 1):47-56.

43. Hui E, Chow J, Li D, Liu J, Wat P, Law H. Immediate provisional for single-tooth implant replacement with Branemark system: preliminary report. Clin Implant Dent Relat Res 2001;3:79-86.

44. Drago CJ, Lazzara RJ. Immediate provisional restoration of Osseotite implants: a clinical report of 18-month results. Int J Oral Maxillofac Implants 2004; 19:534-41.

45. Ericsson I, Nilson H, Lindh T, Nilner K, Randow K. Immediate functional loading of Branemark single tooth implants. An 18 months' clinical pilot follow-up study. Clin Oral Implants Res 2000;11:26-33.

46. Abboud M, Koeck B, Stark H, Wahl G, Paillon R. Immediate loading of single-tooth implants in the posterior region. Int / Oral Maxillofac Implants 2005;20:61-8. 